Review of Income and Wealth

Series 55, Number 1, March 2009

\title{
THE SPATIAL STRUCTURE OF INCOME INEQUALITY IN THE ENLARGED EU
}

\author{
BY ONNO HOFFMEISTER* \\ University of Hamburg
}

\begin{abstract}
This study examines how personal disposable income is distributed across regions, countries and larger geographical areas in the EU25 and how this distribution changed during the second half of the 1990s. Moreover, it assesses the "statistical" effect resulting from the enlargement of the European Union, and therefore the community of people for which inequality is measured. A three-level spatial decomposition of the overall personal inequality in the EU reveals that a fifth of its amount is attributed to the east-west income gap and that intra-regional inequality accounts for three quarters. The study detects a convergence of both average national income levels and within-country personal income inequality. Inequality is rising primarily in the Scandinavian social-democratic welfare states and decreasing in the Mediterranean countries of the EU15. In Eastern Central Europe, the rapid growth of inequality which had been observable during the first years of transition has come to an end.
\end{abstract}

\section{INTRODUCTION}

In the first decade of the new millennium, the European Union (EU) faces a double challenge. On the one hand, it is struggling for a democratization of its institutions of decision making, as foreseen in the draft constitution agreed upon by the Member States' governments in Rome 2004. On the other hand, it has enlarged its territory by integrating 12 new countries, mostly in Central and Eastern Europe - ten in 2004 and two others in $2007^{1}$ — for which average income per capita is considerably lower than for the original EU15. Too high income inequality is commonly considered as a threat for social cohesiveness and democracy in a community. Durkheim (1992, pp. 446-8) develops the thought that inequalities, which prevail between persons for reasons which they cannot be held responsible for, tend to destroy ("organic") solidarity and promote anomic behavior by those who are worse off. Boix (2004, pp. 1-4) shows in a simple model framework that the two objectives, integration of a relatively poor group of people and full participation of citizens in decision-making, counteract each other when the members of the richer and incumbent part of the community are unwilling to share their material resources with the newcomers. Distributional conflicts indeed

Note: I am grateful to Hans-Jürgen Wagener, Viktor Steiner, Wilhelm Pfähler, Branko Milanovic, the team of the GSOEP (DIW Berlin), the participants of the CRISS-Ineq Summer School on Inequality in Siena, and two anonymous referees for their comments on this paper. I would also like to thank the Europa-Fellows Program of the European University Viadrina (Frankfurt/Odra) for its support.

*Correspondence to: Onno Hoffmeister, European Commission, Eurostat, 5, Rue Alphonse Weicker, L-2920 Luxembourg (Onno.HOFFMEISTER@ec.europa.eu).

${ }^{1}$ This study focuses on the enlargement in 2004 in which the following ten countries joined the EU: the Czech Republic, Cyprus, Estonia, Hungary, Latvia, Lithuania, Malta, Slovakia, Slovenia and Poland. They will be referred to as the Accession Countries (AC10). The countries which formed the EU before that enlargement will be referred to as the EU15, and both country groups together as the EU25.

(C) 2009 The Author

Journal compilation (C) 2009 International Association for Research in Income and Wealth Published by Blackwell Publishing, 9600 Garsington Road, Oxford OX4 2DQ, UK and 350 Main St, Malden, MA, 02148, USA. 
played a significant role in the debates about the reform of the European Structural Funds (ESF) in the light of enlargement and on the modification of the voting rules in the Council of the EU.

Being aware of the risk of tensions caused by unequal distribution of income throughout the regions, the European Community agreed on measures to support regions lagging behind in their economic development even in the early phases of its existence. At the Lisbon Summit in 2000, the Member States also voiced their concern about individuals who are excluded from the wealth generated in European society and declared the fight against poverty and social exclusion as a central element of modernizing the European Social Model. However, unlike support given to the regions, the EU does not implement any direct measures to redistribute income on the level of individuals. The formulation and implementation of social policy has remained the sole responsibility of the national governments. This emphasis on the nation state is reflected in the Laeken indicators introduced in the scope of the Lisbon strategy to monitor success in the fight against poverty and social exclusion (cf. Atkinson, 2003).

At present, the Laeken indicators include measures of relative poverty and income inequality, including the Gini coefficient, which are calculated separately for each country. Eurostat derives the figure for the EU25 as the populationweighted average of the national estimates (Eurostat, 2008). This method produces different results than when inequality is measured jointly for the entire population of the EU, because inequality between countries is not taken into account. The country-specific approach has also been followed in many previous studies on income inequality in the EU (see Section 2). However, in an independent report on the Laeken indicators it has been proposed to introduce a new indicator which reports poverty as the share of people whose income falls short of an EU wide poverty line to be defined as 60 percent of the median income of the entire EU (Atkinson et al., 2005, pp. 113-15). This indicator would constitute the first official measure of EU-wide inequality. Some research has already been carried out to analyze poverty (Kangas and Ritakallio, 2004; Förster, 2005) and inequality (Atkinson, 1996; Beblo and Knaus, 2001; Boix, 2004; Morrisson and Murtin, 2004; Brandolini 2007) in a pan-European approach.

But country-wise measurement of inequality and relative poverty is often justified with reference to the theory of relative deprivation. This theory rests on the assumption that a person's well-being is primarily determined by their position relative to the other members of their community, rather than by the absolute value of the resources at their disposal. People form their perception of being or not being deprived on the basis of comparison with others (Runciman, 1966); the community creates expectations on one's way of life, and the resources required to comply with them differ between richer and poorer communities (Townsend, 1979); in richer countries a higher income is needed to uphold a life of dignity and participate in also society for other reasons (Sen, 1983). In this light, deprivation becomes a matter of socialization. Although EU citizens appear to still feel rooted in their national and regional environments (Keating, 1998; Edwards, 2000; Castells, 2002), there is also strong evidence for patterns of international socialization among the inhabitants of the EU. Kaelble (2005) observes a convergence of the social conditions in which Europeans live. Niedermayer (1995) and Delhey 
(2005) show that trust, the key determinant of a sense of community according to Karl Deutsch, is on the rise between inhabitants of different countries. Since 1996 a modestly larger number of respondents reported that they see themselves as being European citizens in the near future, at least complementarily to being citizens of their country (Berger-Schmitt, 2002, pp. 4ff.; Eurobarometer, 2005, pp. 94-6). More and more people are therefore comparing their situation with that of people living abroad. Hence the perceptions of what is an acceptable way of life can be expected to converge throughout the countries. According to Delhey and Kohler's (2006) analysis, cross-national comparisons are already having a significant impact on reported well-being in Europe if inhabitants of the reference country are richer than the respondents themselves. Other studies show that the Member States' relative income position in the EU is an important determinant for individuals' perceived deprivation and economic strain. This applies to the EU15 (Whelan et al., 2001, pp. 364-9) and, to an even larger extent, to the accession countries (Russel and Whelan, 2004; Förster, 2005, pp. 37-41; Fahey, 2007). Hence a pure country-wise measurement of inequality appears to become increasingly obsolete, as it tells us little about how parts of the evolving European society feel unfairly deprived.

The primary goal of this paper is to investigate the extent of income inequality in the EU25, treating the inhabitants of all Member States as a common whole. A spatial decomposition allows us to analyze the statistical effect on inequality caused by the enlargement round of 2004, and to assess the role of regional cohesion and social policies in lowering it. Another goal is to understand the evolution of the spatial pattern of inequality. Inequality will be analyzed at two points in time, in the middle and at the end of the 1990s, and contrasted with the main changes which took place in the economic and institutional environment. The following section reviews the empirical findings of previous studies. Section 3 describes the methodology applied in analysis of the study at hand. The results are presented and discussed in Section 4. Section 5 concludes.

\section{Evidence from Previous Studies}

The development of the regional and national average income levels, measured in terms of the GDP per capita adjusted by purchasing power parities (PPP), is documented in the Cohesion Reports of the European Commission $(2001,2004)$. As a general trend, the differences in the national average GDP per capita across the EU15 countries diminished in the course of the 1990s. But large income differences in the average GDP levels persist between the EU15 and the new Member States. With the exception of Cyprus, none of the countries which joined the Union in May 2004 was more prosperous than the poorest EU15 country in 2002. Thus, in 2004 the regional disparities throughout the EU grew considerably as a consequence of the "statistical effect" of the enlargement. Indeed the gap between the GDP per capita in the least prosperous Member State and the EU average increased from less than 30 percent before enlargement to more than 60 percent after enlargement (European Commission, 2004, pp. ix, 10-12). However, the income gap between the AC10 and the EU15 has become smaller over time. From 1995 to 2003 the difference between the average GDP per capita in the new 
Member States and the EU25 average decreased from 54 to 48 percent of the EU25 level. Nevertheless, in 2003 the average GDP per capita in the AC10 was still not even half as high as in the EU15 (cf. Hoffmeister, 2006).

With respect to within-country income inequality, studies by Atkinson et al. (1995), Gottschalk and Smeeding (1997), Smeeding (2000) and Beblo and Knaus (2001) reveal that in the mid 1990s the ordering of EU15 countries was highly stratified by the type of welfare state. Income was most equally distributed in the Scandinavian countries. More inequality could be found in western central Europe, and inequality was highest in the liberal and Mediterranean countries. ${ }^{2}$ Smeeding (2000) reports rising inequality of income in almost all investigated Member States of the EU15 between the late 1980s and mid 1990s. Inequality only declined in Luxembourg during this time. In the AC10, inequality grew in all countries investigated by Milanovic (1999), although different paths of development can be observed: Slovenia, Hungary, Latvia and Poland entered the period of economic transition with comparatively low inequality at the end of the 1980s. Until the mid 1990s, the Gini coefficient of disposable income increased dramatically in Latvia (by 44 percent) and Poland (by 42 percent), whereas in Slovenia (13 percent) and Hungary (11 percent) the growth of inequality was not as high (Milanovic 1999).

Up to now, few studies have analyzed income inequality across persons jointly for different Member States, which may be attributable to the scarcity of internationally harmonized microdata. Atkinson (1996, pp. 25ff.) makes an attempt, based on data of the Luxembourg Income Study (LIS, 2008), which he calls "at best a prototype" of the estimation of EU inequality. He divides the population of 12 EU15 countries and Norway and Switzerland into 20 or 40 groups per country, with reference to their disposable income. He then aggregates these groups across all countries and calculates decile shares and decile ratios. A similar approach is followed by Morrisson and Murtin (2004), who derive common European inequality measures from the decile and vintile shares in countries' total disposable income. Quantile-wise aggregated income data also forms the basis of the "World Income Distribution Dataset," prepared by Milanovic (2002) on the basis of a variety of different data sources, which has been employed by Boix (2004, pp. 7ff.) for the calculation of Gini coefficients of the EU using different demarcations of EU territory. The Gini coefficient of 0.380 turns out to be 0.037 points higher when calculated for the EU25 instead of EU15.

The supranational measurement of inequality based on secondary datasets like the World Income Distribution Dataset has been criticized, as the aggregates which they provide do not rely on harmonized source data. Atkinson and Brandolini (2001) show that inequality indices for OECD countries calculated on that basis are only modestly correlated to indices derived from the ex-post harmonized microdata from the LIS. Heyns (2005, p. 174) finds albeit a higher yet far from perfect correlation between indices recorded in different secondary datasets. Moreover, the practice of calculating inequality indices from quantile distributions rests on the assumption of zero inequality within the quantiles and thereby produces a measurement error of a size which is difficult to assess.

${ }^{2}$ Headey and Muffels' (2003, pp. 35ff.) comparison of post-tax income distributions in Germany, The Netherlands and the United States between 1987 and 1996 confirms this relationship between inequality and the type of welfare state. 
Beblo and Knaus (2001) and Brandolini (2007) derive supra-national inequality in the EU directly from household data. Beblo and Knaus calculate and decompose a Theil index calculated from the datasets of ten countries of the Eurozone included in the 1995 Round of the European Community Household Panel (ECHP). Transfers paid and received by households are not considered in the income measure, which makes comparison with other studies difficult. Brandolini matches the ECHP data of Round 2000, covering all EU15 countries, with LIS data from five AC10 with reference years between 1996 and 2000. Based on these data he calculates a Gini coefficient, Atkinson indices, quintile and decile ratios. The Gini coefficient rises from 0.294 to 0.328 when the baseline population is extended from the EU15 to the five AC10 included in the study.

To summarize, during the first half of the 1990s the income distribution became more unequal both in countries of the EU15 and AC10. Within the EU15, the countries' average income converged. Furthermore, the income gap between the east and west of the EU narrowed over the entire decade, though toward the end real GDP per capita was still less than half as high in the AC10 as in the EU15. The supra-national Gini coefficient increases between 0.03 and 0.04 points when the baseline population is extended from the EU15 to include the AC10.

The analysis below assesses inequality between inhabitants of EU Member States treated as a common whole, focusing on the second half of the 1990s. It differs from Atkinson (1996) and Beblo and Knaus (2001) in that it covers not only Member States of the EU15 but also the AC10. AC10 are indeed included in the studies of Boix (2004), Morrisson and Murtin (2004) and Brandolini (2007). However, Boix and Brandolini do not provide decompositions of inequality into within- and between-group components. Thus, their results do not enable us to infer to what extent inequality would reduce if between-group differences in average income were absent. By decomposing inequality on three geographic levels, the present analysis goes further than the decompositions presented by Morrisson and Murtin and Beblo and Knaus and thereby provides a more detailed picture of the spatial distribution of income. By computing the inequality measures directly from harmonized household-level microdata, the estimate of inequality is supposed to be more exact than those from the previous analyses.

\section{Methodology}

\section{Levels of Spatial Decomposition}

For assessing the actual and theoretical impact of regional cohesion and social policies in Europe, it appears relevant to decompose the personal inequality of income on the following geographic levels. The first comprises the EU15 and the AC10. The huge income gap between these two parts of Europe has been intensively discussed since the idea of enlargement was born. The second level is that of the nation states, which play the key role in the redistribution of income across their citizens. The national governments are not only assigned the responsibility for social policy in the EU but also initiate cross-regional financial transfers within their countries to a certain extent. Nation states are also the reference unit for the 
allocation of resources from the Cohesion Fund. For the third level of decomposition, attention shall be given to the administrative territorial units below the national level, as they are the main recipients of resources allocated through the EU's and Member States' regional policies. The employed geographic division on the sub-national level is aimed to reflect the countries' administrative structure, along which cross-regional transfers are typically conducted. At the same time, the defined regions should be similar in terms of population size, because this size influences the calculated shares of within- and between-regional inequality. Commonly, the larger the regions are, the greater the measured within-regional component becomes relative to the between-regional component (Shorrocks and Wan, 2005).

Eurostat's Nomenclature of Territorial Units for Statistics (NUTS) takes both criteria just mentioned into account. It assigns priority to the institutional boundaries, while at the same time maximum and minimum thresholds of population size have been set up for each geographic hierarchy level. The NUTS2 classification is generally considered to correspond most closely with the framework which Member States use for their regional policy and is therefore recommended as the appropriate level for the investigation of "regional-national problems" (Eurostat, 2007). It is also applied for the identification of the regions eligible for support from the ESF. Unfortunately, many NUTS2 regions are too small to guarantee that the regional inequality measures derived from the available LIS data are representative for the population of the regions. For that reason, regional identifiers on the NUTS2 level are lacking in most datasets. As a second best solution, the analysis below is based on the next hierarchy level, NUTS1, in the third stage of the decomposition. According to Eurostat, the use of NUTS1 is especially recommended for studies on regional Community problems, such as "the effect of customs union and economic integration on areas at the next level down from national areas" (Eurostat, 2007). NUTS1 regions have been defined by Eurostat so as to ideally cover between 3 and 7 million people. However, there are exceptions to this rule as the administrative division is the main classification criterion. $^{3}$

\section{Data Sources}

The LIS makes available data on private household income collected in large representative interview surveys in a variety of countries. It offers a unique opportunity for cross-country studies on personal income inequality. The analysis presented below is based on information reported by roughly 230 thousand households in 18 countries of the EU25. For this study, the household weights stored in the LIS database have been inflated so as to sum up to the population total of the NUTS1 region (in the survey round 1999/2000) or country (in round 1994/1995) as reported in Eurostat's New Cronos database. The EU15 is represented by all of its Member States except Portugal. Among the AC10, Cyprus, the Czech Republic, Latvia, Lithuania, Malta and Slovakia are missing. The 18

\footnotetext{
${ }^{3}$ Among the countries investigated in this study, the NUTS1 regions' average population size is especially large in Italy and Sweden. At the opposite end of the scale, small countries like Luxembourg, Estonia and Slovenia are composed of only one NUTS1 region with less than 3 million inhabitants.
} 
countries of the LIS sample account for 93 percent of the total population of the EU25-98 percent of the inhabitants in the EU15 and 69 percent of the inhabitants in the AC10. Based on the surveyed information about the gross household income, tax payments, social security contributions and other deductions from income, the LIS has generated a harmonized measure of household disposable income.

\section{Adjustment for Differences in Needs and Prices Levels}

Taking into account differences in needs between households of different size, household disposable income, as generated by the LIS, has been transformed into equivalized disposable income (EDI) by dividing it by the square root of the household size. The resulting amount has been assigned to each person in the household. The needs of members of larger households are considered to be lower than those of others, because people commonly save costs when they share a common habitation.

The choice of the equivalence scale has an impact on the measured income inequality. Coulter et al. (1992, p. 1081) demonstrate that the relationship between the weight attached to additional persons in the household and the measured inequality is $\mathrm{U}$-shaped. Inequality has a minimum somewhere between the equivalence scale values one and the number of persons in the household. Buhmann et al. (1988, pp. 128ff.) show that in EU15 countries this minimum is commonly reached when the household-size elasticity of the equivalence scale is between 0.25 and 0.72 . The values of customary inequality measures in OECD countries differ considerably depending on the applied equivalence scale. In Brandolini's (2007) analysis, the measured Gini coefficient takes values between 0.357, when the equivalence scale equals the household size, and 0.328 , when other common scales are applied.

If we expect an equivalence scale to accurately reflect the differences in the cost of living between persons living in different types of households, one might apply different scales in different countries. By contrast, if we expect it to reflect a social planner's subjective judgment about the persons' needs, it appears preferable to apply the same judgment in all investigated countries and define the equivalence scale universally. The application of the "square-root scale" chosen for this study, which implies a household-size elasticity of 0.5 , should be understood as a subjective judgment. This judgment provides a good compromise between official equivalence scales used in many countries of the OECD, as Atkinson et al. (1995) show.

The household data analyzed below refer to different countries and different years. As income is intended to be employed as a measure of welfare, differences in the cost of living across time and space should be taken into account. For that purpose, the nominal EDI, which is expressed in local currency units at current prices, is deflated by the temporal price index of household final consumption expenditure (HFCE) and transformed into PPP for the year 2000 calculated by the PPP from Eurostat (2008) for that consumption aggregate. ${ }^{4}$ One euro of

${ }^{4}$ The currencies of the Eurozone countries had to be divided by the convergence rate between local currency and the Euro, because the PPPs of these countries are based on the Euro. 
PPP-adjusted income can be thought of as the cost of an average consumption basket equivalent to 1.06 Euros spent in Germany. The data of the geographic and temporal price deflators are given in Table A1 in the Appendix.

The method of adjustment for geographic and temporal differences in prices indeed leads to a certain degree of inaccuracy. First, as income deflators are only available at the level of countries, differences in the cost of living on the subnational level are not seen in the analysis below. Commonly, prices are higher in richer regions. Accordingly, the true cross-regional and interpersonal inequality within countries can be expected to be modestly overstated by the results presented below. Second, the employed PPP and temporal price indices are biased by the Gerschenkron effect (Eurostat and OECD, 2006, pp. 130ff.). This effect arises from the fact that the price indices are calculated on the basis of weights reflecting fixed expenditure shares, while in reality households with different levels of standard of living consume goods in different proportions and relatively expensive goods are substituted with cheaper ones. Hill (2000) finds that the world's poorest countries' per-capita incomes are overestimated by up to 70 percent as a consequence of the Gerschenkron effect, if income is deflated by the PPP of the World Bank (see also Dowrick and Akmal, 2005). Eurostat applies a different method of aggregation of expenditure categories, called the EKS method, which is based on geometric weighting and which should lead to a weaker substitution bias, but the Gerschenkron effect cannot be completely avoided.

\section{Comparison of Income across Countries}

The difficulties in comparisons of household income across countries are not limited to the problem of accurate assessment of the cost of living. The surveys which provided the source data for the measurement of EDI apply different designs and measure income in different ways. Accordingly, although the data have been harmonized ex-post by the LIS, the extent of underreporting is likely to differ between the countries, and certain sources of income are included in the definition of income in some countries but not in others (Smeeding and Weinberg, 2001). By comparing the national averages of household income obtained from the LIS with the corresponding amount reported by external sources, Atkinson et al. (1995) find an under-reporting of the LIS data of between 7 and 23 percent in different countries.

The effect of measurement error on reported inequality within a country is difficult to be adjusted for, as better data on the income distribution within the countries are not available. By contrast, for the correction of between-country inequality, it is possible to make use of the National Accounts. Eurostat publishes the household net disposable income (HNDI) per capita of all EU25 countries as part of the European National Accounts. HNDI is derived by subtracting taxes, current transfers paid net of current transfers received, and fixed capital consumption from the gross national income (GNI) of the household sector. Indeed the microdata and National Accounts approaches to measurement of household income are rooted in different traditions and partly serve different purposes. While the emphasis of the microdata approach is on measurement of economic wellbeing and its distribution among individuals, the focus of the National Accounts 
is on expressing the interrelationships between the various sectors of an economy, one of which is the household sector. Nevertheless, both approaches are meant to arrive at the measurement of more or less the same thing: the maximum amount which individuals can spend on consumption in a given period of time without reduction of their assets (Expert Group on Household Income Statistics, 2001, pp. 5ff., 16ff.).

It has become standard practice in the literature on world income inequality to merge household survey data with mean income levels from the National Accounts, although this practice has also been criticized (Brandolini, 2007, pp. 9-11). Below, the results obtained with these two methods will be compared by applying both mean EDI obtained from microdata and HNDI from the National Accounts for the assessment of between-country inequality. The Cohesion Reports of the EU analyze the relative differences between regions and countries with regard to their average GDP per capita. Many studies use gross national income (GNI) which differs only modestly from GDP. ${ }^{5}$ The difference between GDP and HNDI, the largest part of which constitutes the income of the government sector, is commonly positively correlated to the average GDP and thus exerts a smoothening effect on the measured cross-national inequality (Brandolini, 2007, pp. 10ff.; Svennebye, 2008, p. 3). With the aim to investigate the size of that effect, both real HNDI and real GDP are employed in the analysis below. Their figures for 1995 and 2000 are presented in Table A2 in the Appendix.

\section{Inequality Measurement}

Theil's (1967) Generalized Entropy Indices are the only differentiable, symmetric and homogenous inequality measures that can be additively decomposed into subgroups (Bourguignon, 1979; Cowell, 1980; Shorrocks, 1980). One indicator belonging to this family is the Mean Logarithmic Deviation (MLD), which is defined as

$$
D=\frac{1}{N} \sum_{i=1}^{N} \ln \left(\frac{\mu}{y_{i}}\right),
$$

where $y_{i}$ is the $i$-th person's income and $\mu$ is the mean income calculated over all $N$ persons. The MLD satisfies the most common properties of inequality indices: scale invariance, the principle of diminishing transfers and zero normalization. ${ }^{6,7}$ However, it is the only index of the Generalized Entropy family which leads to a path-independent decomposition (Shorrocks and Wan, 2005). Path-independency, as defined by Foster and Shneyerov (2000), implies that the within-component is unaffected by changes in the subgroups' average income levels. As a consequence,

\footnotetext{
${ }^{5}$ The difference between GDP and GNI is made up by net trading gains from changes in the terms of trade and net incomes received abroad.

${ }^{6}$ Scale invariance means that the measured inequality does not change if everybody's income is multiplied by the same factor, as is the case, for example, with inflation rates. The principle of diminishing transfers implies that inequality reduces whenever income is transferred from a richer to a poorer person, leaving their rank order unchanged. Zero-normalization requires that the inequality index is zero if all individuals earn the same amount of income.

${ }^{7}$ However, unlike most other inequality indices, the MLD is unbounded from above. It can take values greater than one if inequality is extraordinarily high.
} 
if income is transferred from one subgroup to another in a way that the distribution of personal incomes relative to the subgroup means does not change in each subgroup, the within-component of the MLD remains the same. This property is particularly desirable for the present study to illustrate the potential effects of redistribution of income conducted at different geographic levels on the overall inequality. An income transfer of the type mentioned above can be thought of, for example, as a proportional tax levied on the members of one subgroup, the revenues of which are proportionally distributed among the members of another.

The path-independency of the MLD is due to the fact that the within-group component is derived by taking the purely population-weighted average of the MLD levels observed in each subgroup. Accordingly, if two regions are equal in population size but their average income is different, the MLD assigns a reduction of inequality within each of these regions equal importance. By contrast, in the Theil index, which has been employed, for example, by Beblo and Knaus (2001), the regions are represented with weights proportional to their income shares. The authors' choice has been driven by the intention to accentuate the "countries" economic standings in terms of political power within the European Monetary Union" rather than to "evaluate the effectiveness of distribution policies" (Beblo and Knaus, 2001, p. 307). The emphasis in the present study is on the second of the aforementioned research goals.

The MLD is less frequently applied as an inequality measure than the Gini coefficient. If the Gini coefficient is additively decomposed, it only falls entirely into within- and between-group components if the richest member of any poorer group is poorer than the poorest member of any richer group. In all other cases, there remains an "overlap component" which provides interesting information about the population's stratification (cf. Pyatt, 1976; Yitzhaki and Lerman, 1991; Lambert and Aronson, 1993; Yao and Liu, 1996). The primary focus of this study is not on stratification but on the relative importance of the inequalities occurring within and between regions. The complete decomposition of the MLD into withinand between-regional components enables exact specification of the amount of inequality which could be avoided if income levels within certain regions were fully equalized or all regional disparities removed. This applies to the Gini coefficient only in very specific circumstances which do not prevail in the EU.

Bourguignon (1979), Cowell (1980) and Shorrocks (1980) demonstrate how the MLD is decomposed into subgroups. For the analysis below, this decomposition is repeated three times on the different geographic levels outlined above. Let us assume that $N$ Europeans are spread over $K$ country groups (the EU15 and the AC10), each of which incorporates $n_{k}$ persons. Each country group is composed of $L_{k}$ countries with $n_{k, l}$ inhabitants living in the $l$-th country of the country group $k$. Furthermore, each country $l$ in country group $k$ is composed of $M_{k, l}$ regions with $n_{k, l, m}$ inhabitants in each of them. Then, the MLD given in equation (1) can be rewritten as

$$
D=\left[\sum_{k=1}^{K} \sum_{l=1}^{L_{k}} \sum_{m=1}^{M_{k, l}} \frac{n_{k, l, m}}{N} D_{k, l, m}\right]+\left[\sum_{k=1}^{K} \sum_{l=1}^{L_{k}} \frac{n_{k, l}}{N} D_{k, l}^{B}\right]+\left[\sum_{k=1}^{K} \frac{n_{k}}{N} D_{k}^{B}\right]+D^{B},
$$


where $D^{B}$ is the MLD which measures the inequality of the country groups' mean income levels $\left(\mu_{k}\right)$,

$$
D^{B}=\sum_{k=1}^{K} \frac{n_{k}}{N} \ln \left(\frac{\mu}{\mu_{k}}\right)
$$

$D_{k}^{B}$ is the MLD which measures the inequality of the countries' mean income levels within country group $k\left(\mu_{k, l}\right)$,

$$
D_{k}^{B}=\sum_{l=1}^{L_{k}} \frac{n_{k, l}}{n_{k}} \ln \left(\frac{\mu_{k}}{\mu_{k, l}}\right),
$$

$D_{k, l}^{B}$ is the MLD which measures the inequality of the regions' mean income levels within the $l$-th country of country group $k\left(\mu_{k, l, m}\right)$,

$$
D_{k, l}^{B}=\sum_{m=1}^{M_{k, l}} \frac{n_{k, l, m}}{n_{k, l}} \ln \left(\frac{\mu_{k, l}}{\mu_{k, l, m}}\right),
$$

and $D_{k, l, m}$ is the MLD which measures the interpersonal inequality within the respective region,

$$
D_{k, l, m}=\sum_{i=1}^{n_{k, l, m}} \frac{1}{n_{k, l, m}} \ln \left(\frac{\mu_{k, l, m}}{y_{i}}\right)
$$

\section{Results}

Personal Inequality of the EU25

In 1999 and 2000, the total interpersonal inequality measured throughout the LIS sample amounted to 0.215 points of the Mean Logarithmic Deviation (MLD). It was composed of 0.165 MLD points average personal inequality within countries (accounting for 76.6 percent), 0.006 MLD points average between-country inequality within the EU15 and AC10 respectively (accounting for 2.8 percent), and 0.044 MLD points attributed to the income gap between these two groups of countries (accounting for 20.6 percent of the overall MLD). This decomposition is shown on the left-hand side of Table 1.

The MLD obtained on the basis of the LIS sample is likely to provide an inaccurate estimate of the MLD of the entire EU25, because seven Member States are missing, six of which are AC10. As a result, 98 percent of the population of EU15 but only 69 percent of the population in the AC10 are represented in it. In contrast, data on average HNDI per capita are available for all Member States of the EU25 from the European National Accounts. An estimate of between-country inequality on the basis of these data might produce more accurate results. They not only cover the entire set of countries but may also be viewed as more comparable across countries from a certain perspective (see Section 3). The between-country inequality in the entire LIS sample — obtained as the average of between-country 
measured with EDI. The size of this deviation is not too large. In the test carried out with the LIS country sample it amounted to 4 percent of the personal MLD measured purely with EDI data. Which of the two estimates is more reasonable to apply cannot be decided here. The disputed question as to whether EDI or HNDI is the more accurate aggregate for measuring cross-national inequality has not yet been solved.

Comparing overall personal inequality in the EU15 with that of the EU25 allows us to quantify the statistical effect of the enlargement - under the assumption that this enlargement had already taken place by the year 2000 . The inequality of the EU15, calculated on the basis of the extrapolated data, amounts to 0.173 (the sum of 0.166 and 0.007 ) MLD points, as compared to 0.216 MLD points inequality in the EU25. Thus, the enlargement made the inequality between persons rise by 25 percent. The statistical effect of enlargement on the Gini coefficient, derived by Boix (2004) and Brandolini (2007), was smaller. It amounted to only around 11 percent. This difference is not surprising, as the MLD reacts more sensitively than the Gini coefficient to changes taking place in the lower segments of the income distribution. Furthermore, we note that the MLD of the EU25 is higher than in all, except one, of its constituent Member States (see the eighth column of Table 3). The exception is represented by Estonia, which shows a within-country MLD of 0.224 points. The figures for the United Kingdom and the Mediterranean EU15 countries come fairly close to the amount of the EU25 as well. Greater inequality has been reported by other studies for some large countries, such as Russia in 1999 (0.33 MLD points), Canada in 1997 (0.31 MLD points), the Philippines in 1997 (0.30 MLD points), or Indonesia in 1993 (0.23 MLD points) (Shorrocks and Wan, 2005). Thus, an inequality of around 0.22 MLD points in the EU25 does not appear exceptionally high. However, the comparability of the results with those of other studies is rather limited due to differences in income measurement and survey design.

\section{Development of Inequality over Time}

How did income inequality within and between EU countries develop during the second half of the 1990s? Except for Estonia, we can investigate the distribution of EDI within all the 18 Member States included in the LIS sample at two points in time: in 1994/1995 and 1999/2000. For Slovenia, however, the reference year in the first round is 1997. The lower part of Table 1 shows how the inequality and its geographic composition evolved throughout the EU25. We observe a convergence on all geographic levels: the inequality within countries fell in both parts of Europe. In the AC10 the decline was so strong that the two country groups swapped places. In the mid 1990s, with an amount of 0.176 MLD points on average, the within-country inequality of the AC10 group had exceeded that of the EU15 gradually by to 0.004 points, but with an amount of 0.155 MLD points it was already 0.011 points smaller by the end of the decade. ${ }^{8}$ During the same period of time, the between-country inequality fell in the EU15 modestly

\footnotetext{
${ }^{8}$ The difference in 1999/2000 would be even greater if Estonia was excluded from the sample, so that the same set of countries would be observed at both points in time; see the figures of within-country inequality in the upper part of Table 2.
} 
TABLE 3

Robustness of Measured Between-Country Inequality to Changes in the Income Aggregate

\begin{tabular}{|c|c|c|c|c|c|c|c|}
\hline \multirow[b]{3}{*}{ Income Aggregate } & \multicolumn{6}{|c|}{ MLD } & \multirow[b]{3}{*}{ Divergence $^{1}$} \\
\hline & \multicolumn{2}{|c|}{$\begin{array}{l}\text { Between MS } \\
\text { in EU15 }\end{array}$} & \multicolumn{2}{|c|}{$\begin{array}{l}\text { Between } \\
\text { AC10 }\end{array}$} & \multicolumn{2}{|c|}{$\begin{array}{l}\text { Between EU15 } \\
\text { and AC10 Group }\end{array}$} & \\
\hline & 1995 & 2000 & 1995 & 2000 & 1995 & 2000 & \\
\hline Nominal HNDI/HFCE price index & 0.0100 & 0.0073 & 0.0269 & 0.0162 & 0.0509 & 0.0435 & -0.597 \\
\hline Nominal HNDI/GDP price index & 0.0067 & 0.0056 & 0.0245 & 0.0128 & 0.0452 & 0.0371 & -0.563 \\
\hline Nominal GDP/GDP price index & 0.0078 & 0.0062 & 0.0281 & 0.0158 & 0.0424 & 0.0347 & -0.360 \\
\hline
\end{tabular}

(from 0.010 to 0.007 MLD points) and more strongly among the AC10 (from 0.027 to 0.016 MLD points). In 1999/2000 it still remained higher in the latter group of countries. Finally, the income gap between the EU15 and the AC10 narrowed, from 0.051 to 0.043 points of the MLD. Altogether, the interpersonal inequality of the EU25 shrank from 0.237 to 0.216 MLD points. A similar convergence at all geographic levels can be observed by applying the pure nonextrapolated LIS data, with the exception that they do not indicate any fall of between-country inequality in the EU15 (see the upper part of Table 2).

Data on HNDI and the price index for HFCE are not always available in cross-national research on income inequality. Researchers often use real GDP or GNI as a substitute, or they may feel tempted to divide nominal HNDI by the GDP deflator. Let us check the robustness of the estimated between-country inequality to those modifications. For this, the calculations above are redone twice: firstly, after the (temporal and cross-national) HFCE price index, applied in the calculation of real HNDI, has been replaced by the GDP price index, and once again, after real HNDI has been replaced by real GDP (i.e. nominal GDP divided by the GDP price index). The results of these checks are presented in Table 3. They reveal the expected effect that between-country inequality commonly appears smaller with GDP than with HNDI data (with the exception of between-country inequality among AC10 around 1995). The measured between-country inequality also shrinks in response to replacing the HFCE by the GDP price index. Effects in the same direction on the EU25-wide Gini coefficient have been observed by Brandolini (2007, p. 27), after he had replaced HNDI by GNI or applied the GDP price index. Independently from those effects on the levels of measured inequality, it can be inferred from Table 3 that the development over time reveals similar trends with and without the modifications just described: the income gap between the east and west EU narrows, the between-country inequality falls in both parts of Europe, and this fall is more pronounced in the AC10 than in the EU15.

Let us now examine the personal inequality of each particular country in the middle and at the end of the last decade. The countries presented in Table 4 are sorted in ascending order of their personal inequality observed in 1994 or 1995. At that time, we could find the EU15 countries arranged according to the same 
TABLE 4

Development of Member States' Within-Country Inequality and Mean Disposable Income ACCORDING TO LIS DATA

\begin{tabular}{|c|c|c|c|c|c|c|c|c|c|c|}
\hline \multirow[b]{2}{*}{ Country } & \multicolumn{4}{|c|}{ Round 1} & \multicolumn{4}{|c|}{ Round 2} & \multicolumn{2}{|c|}{$\begin{array}{l}\text { Annual } \\
\text { Growth }\end{array}$} \\
\hline & Year & $\begin{array}{c}\text { EDI } \\
{\text { (Euro) })^{1}}^{1}\end{array}$ & MLD & $\begin{array}{l}\text { No. of } \\
\text { Obs. }\end{array}$ & Year & $\begin{array}{c}\text { EDI } \\
\text { (Euro) }^{1}\end{array}$ & MLD & $\begin{array}{l}\text { No. of } \\
\text { Obs. }\end{array}$ & $\begin{array}{l}\text { EDI } \\
(\%)\end{array}$ & $\begin{array}{c}\text { MLD } \\
(\%)\end{array}$ \\
\hline Finland & 1995 & 13,564 & 0.0818 & 9,257 & 2000 & 14,865 & 0.1112 & 10,419 & 1.8 & 6.3 \\
\hline Denmark & 1995 & 17,158 & 0.0882 & 79,922 & 2000 & 18,582 & 0.0892 & 81,904 & 1.6 & 0.2 \\
\hline Luxembourg & 1994 & 27,300 & 0.0906 & 1,813 & 2000 & 29,066 & 0.1094 & 2,418 & 1.1 & 3.2 \\
\hline Sweden & 1995 & 13,354 & 0.1056 & 16,221 & 2000 & 15,829 & 0.1199 & 14,471 & 3.5 & 2.6 \\
\hline Slovenia & 1997 & 10,382 & 0.1114 & 2,576 & 1999 & 10,503 & 0.1125 & 3,858 & 0.6 & 0.5 \\
\hline Belgium & 1995 & 16,845 & 0.1290 & 2,627 & 2000 & 19,581 & 0.1845 & 2,359 & 3.1 & 7.4 \\
\hline Netherlands & 1994 & 15,802 & 0.1342 & 5,134 & 1999 & 17,656 & 0.1358 & 4,968 & 2.2 & 0.2 \\
\hline Germany & 1994 & 16,538 & 0.1356 & 6,367 & 2000 & 18,250 & 0.1280 & 10,979 & 1.7 & -0.9 \\
\hline France & 1995 & 16,011 & 0.1430 & 11,286 & 2000 & 16,483 & 0.1298 & 10,287 & 0.6 & -1.9 \\
\hline Austria & 1995 & 16,083 & 0.1459 & 19,248 & 2000 & 19,087 & 0.1175 & 2,344 & 3.5 & -4.2 \\
\hline Poland & 1995 & 4,746 & 0.1764 & 31,562 & 1999 & 5,963 & 0.1558 & 31,375 & 5.9 & -3.0 \\
\hline Hungary & 1994 & 5,981 & 0.1864 & 1,929 & 1999 & 5,718 & 0.1490 & 2,013 & -0.9 & -4.4 \\
\hline Ireland & 1995 & 13,081 & 0.2011 & 2,824 & 2000 & 16,630 & 0.1856 & 2,447 & 4.9 & -1.6 \\
\hline Italy & 1995 & 13,561 & 0.2098 & 8,101 & 2000 & 14,365 & 0.2069 & 7,923 & 1.2 & -0.3 \\
\hline UK & 1995 & 16,125 & 0.2161 & 6,750 & 1999 & 18,442 & 0.2102 & 24,824 & 3.4 & -0.7 \\
\hline Spain & 1995 & 13,069 & 0.2254 & 5,861 & 2000 & 16,025 & 0.2068 & 4,755 & 4.2 & -1.7 \\
\hline Greece & 1995 & 10,193 & 0.2255 & 4,775 & 2000 & 11,295 & 0.2001 & 3,805 & 2.1 & -2.4 \\
\hline Estonia & I & I & I & I & 2000 & 4,841 & 0.2237 & 6,026 & I & I \\
\hline Divergence $^{2}$ & & & & & & & & & -0.163 & -0.589 \\
\hline
\end{tabular}

clusters as identified in previous studies by Atkinson et al., Smeeding, and Beblo and Knaus (see Section 2). The Scandinavian countries, with inequality between 0.08 and 0.10 MLD points, were located at the one end of the scale and the Mediterranean countries, with inequality between 0.21 and 0.23 MLD points, at the other. Between those groups lay the western central European countries, except Luxembourg, where the MLD ranged between 0.12 and 0.16 points. In Ireland and the United Kingdom the inequality was equally as high as in the Mediterranean Member States of the EU15, amounting to 0.20 and 0.22 MLD points respectively. The three AC10, for which LIS data are available, did not form a cluster of their own. Instead, the LIS data confirm Milanovic's findings of a still comparatively low inequality in Slovenia and higher inequality in Poland in the mid 1990s (see Section 3). However, the evidence that Hungary showed a more unequal distribution of income than Poland stands contrary to Milanovic's results.

During the second half of the decade, the inequality increased considerably in all Scandinavian countries, especially in Finland, and fell in all observed Mediterranean ones. As a result, the stratum of Scandinavia overlapped with that of western central Europe-Sweden now revealed more inequality than Austriaand the Mediterranean countries moved closer to the latter. The United Kingdom dropped to the lowest rank among the observed EU15 countries, although the inequality decreased there as well. In the $\mathrm{AC} 10$ the rapid rise of inequality 
observed by Milanovic at the beginning of the decade obviously came to an end. The MLD of Hungary fell on average by more than 4 percent each year, the MLD of Poland by 3 percent, while the MLD of Slovenia remained constant. All in all, we observe a convergence of interpersonal inequality throughout the countries. The average annual growth rate of the MLD (last column of the table) correlates to the initial MLD value (fourth column) by a factor of -0.589 .

The growth of national average EDI levels is also negatively, although modestly, correlated to their levels in 1994/1995 (by a factor of -0.163 ), which corresponds to finding of a reduction of between-country inequality throughout the LIS sample presented above. The strength of that correlation increases considerably (to -0.597) once the country means of EDI are replaced by HNDI per capita. This can be seen from the eighth column of Table 3. The absolute value of the correlation coefficient diminishes modestly if the GDP price index is employed and falls more strongly if real HNDI is replaced by real GDP.

\section{Decomposition of Inequality on the Level of NUTS1 Regions}

So far, the inequality observed between persons in the EU25 as a whole has been decomposed on the level of country groups (EU15 and AC10) and on the level of Member States. Let us now zoom in on the spatial distribution of income on the sub-national level. Table A3 in the Appendix shows the results of a decomposition of personal inequality within Member States into inequality within and between NUTS1 regions for all countries which do not represent a NUTS1 region by themselves and for which data are available. Except for The Netherlands, all datasets in of the LIS sample comprise the regional identifier required to assign the surveyed households to NUTS1 regions. Thus, for the assessment of withincountry regional inequality only three countries, the Czech Republic, The Netherlands and Portugal are missing.

In Table A3, the countries have been arranged in ascending order of their between-region inequality and the regions in ascending order of their personal inequality. The between-region inequality is lowest in the smallest countries of the table: Austria and Belgium. Both incorporate only three NUTS1 regions. Regional inequality appears highest in the Mediterranean Member States, especially in the "divided economy" of Italy (European Commission, 2001, p. 6). Germany is ranked fourth, although it incorporates five former socialist regions in which average disposable income is still comparatively low. Narrowing the focus further and looking at the inequality within regions, we find that it is often the regions incorporating the capital or a larger urban agglomeration which show the highest levels of personal inequality (for example Ostösterreich in Austria, Hamburg and Berlin in Germany, London in the United Kingdom, Centralny in Poland).

The within-regional inequality amounts to on average 0.155 MLD points, the between-region inequality within countries to 0.009 . This average is taken over all Member States in the LIS sample for which the regional inequality is known, including those comprising only one NUTS1 region and thus having zero regional inequality. As shown in Table 5, the between-region inequality is higher in EU15 countries (0.010 MLD points) than in AC10 (0.004 MLD points), here represented just by Hungary and Poland. We obtain the between-region inequality of the east 
TABLE 5

INEQUALITY BETWEEN NUTS1 Regions IN EUROPE 1999/2000

\begin{tabular}{|c|c|c|c|c|c|c|c|c|c|}
\hline & & \multicolumn{4}{|c|}{ LIS $^{1}$} & \multicolumn{4}{|c|}{ National Accounts ${ }^{2}$} \\
\hline & & \multirow{3}{*}{$\begin{array}{c}\text { Popul. } \\
\text { Share } \\
(\%)\end{array}$} & \multirow[b]{3}{*}{ Abs. } & \multicolumn{2}{|l|}{ MLD } & \multirow{3}{*}{$\begin{array}{c}\text { Popul. } \\
\text { Share } \\
(\%)\end{array}$} & \multicolumn{3}{|c|}{ MLD } \\
\hline \multicolumn{2}{|c|}{ Geographic Unit } & & & \multicolumn{2}{|c|}{ Contribution $^{3}$} & & \multirow[b]{2}{*}{ Abs. } & \multicolumn{2}{|c|}{ Contribution $^{3}$} \\
\hline Within & Between & & & Abs. & $(\%)$ & & & Abs. & $(\%)$ \\
\hline MS of EU15 & Regions $^{4}$ & 84.5 & 0.0098 & 0.0083 & 16.5 & 83.5 & 0.0098 & 0.0082 & $\overline{13.4}$ \\
\hline EU15 & $\mathrm{MS}$ & 84.5 & 0.0052 & 0.0044 & 8.7 & 83.5 & 0.0073 & 0.0061 & 10.0 \\
\hline EU15 & Regions & 84.5 & 0.0150 & 0.0127 & 25.2 & 83.5 & 0.0171 & 0.0143 & 23.4 \\
\hline $\mathrm{AC} 10$ & Regions $^{5}$ & 15.5 & 0.0041 & 0.0006 & 1.3 & 16.5 & 0.0041 & 0.0007 & 1.1 \\
\hline AC10 group & $\mathrm{MS}$ & 15.5 & 0.0066 & 0.0010 & 2.0 & 16.5 & 0.0162 & 0.0027 & 4.4 \\
\hline AC10 group & Regions & 15.5 & 0.0107 & 0.0017 & 3.3 & 16.5 & 0.0203 & 0.0034 & 5.5 \\
\hline EU25 & EU15-AC10 & 100.0 & 0.0360 & 0.0360 & 71.6 & 100.0 & 0.0435 & 0.0435 & 71.1 \\
\hline EU25 & Regions & 100.0 & 0.0504 & 0.0504 & 100.0 & 100.0 & 0.0611 & 0.0611 & 100.0 \\
\hline $\begin{array}{l}\text { Notes: } \\
{ }^{1} \text { Without } \\
{ }^{2} \text { Between } \\
{ }^{3} \text { MLD w } \\
{ }^{4} \text { Without } \\
{ }^{5} \text { Without } \\
\text { For abbr } \\
\text { Source: }\end{array}$ & $\begin{array}{l}\text { Cyprus, Czech } \\
\text { region inequali } \\
\text { ighted by the } p \\
\text { regions in Neth } \\
\text { regions in the } \\
\text { viations, see T } \\
\text { IS; Eurostat, N }\end{array}$ & $\begin{array}{l}\text { Republic } \\
\text { y within } \\
\text { opulation } \\
\text { erlands a } \\
\text { zech Re } \\
\text { ble } 1 \text {. } \\
\text { ew Cron }\end{array}$ & $\begin{array}{l}\text { Latvia, } \\
\text { MS imp } \\
\text { share. } \\
\text { hd Portu } \\
\text { ublic. }\end{array}$ & $\begin{array}{l}\text { ithuania, } \\
\text { ted from } \\
\text { al. }\end{array}$ & $\begin{array}{l}\text { Malta, } \\
\text { LIS. }\end{array}$ & Portugal & and Slov & kia. & \\
\hline
\end{tabular}

and west EU respectively by adding their between-country inequality to that amount. According to the extrapolated data, it receives a value of 0.017 MLD points in the EU15 and 0.020 MLD points in the AC10 (see the right-hand side of Table 5). We can calculate the overall between-region inequality of the EU25 by taking the population-weighted average of those two values and adding the between-EU15-AC10 component. The resulting amount is 0.061 MLD points. If we relied on the pure LIS data, we would obtain an amount of only 0.050 MLD points. Thus, between-region inequality accounts for roughly a quarter of the total inequality between the inhabitants of the EU25 (28 percent according to the extrapolated data, 25 percent according to the pure LIS data).

Figure 1 provides a final overview of the development of the spatial structure of personal inequality in the EU25 in the second half of the last decade. As noted above, the inequality declined in absolute terms at all geographic levels: between persons within countries, between countries within the EU15 and AC10 groups respectively, as well as between the two parts of Europe. In relative terms, the share of personal inequality within countries modestly increased, from 73 to 76 percent, at the expense of the other two components. Four of these 76 percentage points are attributable to regional inequality within countries and the remaining 72 percentage points to personal inequality within regions.

\section{Discussion}

As shown above, a personal inequality of 0.216 MLD points has been calculated for the EU25 based on the extrapolated database. This estimate has been derived by applying the average within-country inequality observed in the microdata, which represents 97 percent of the population in the EU25, to the total 


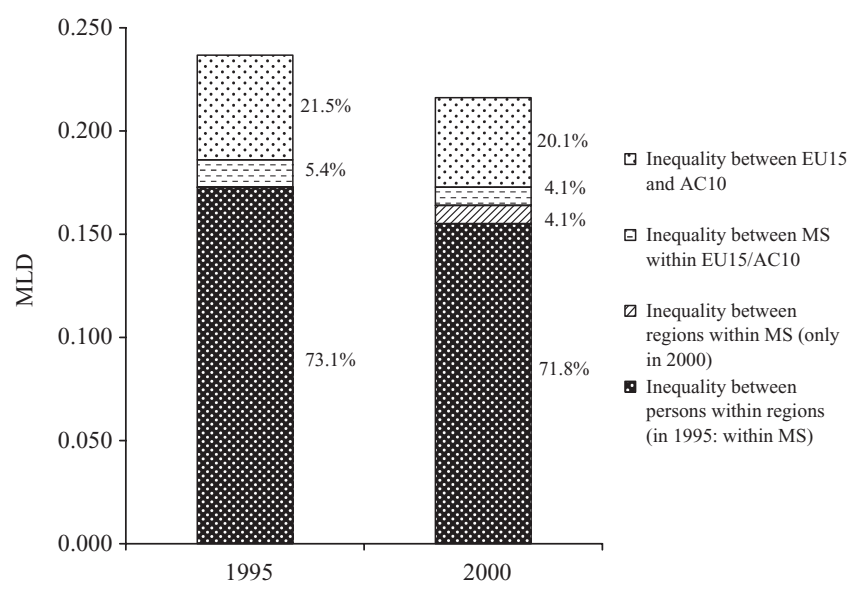

Figure 1. Development of the Spatial Structure of Inequality of the EU25

Notes:

${ }^{1}$ Calculated on the basis of LIS data extrapolated to average HNDI and total population of the EU15 and the AC10.

population numbers of the respective country group and then imputing the between-country inequality reported by the National Accounts. An analysis based on a sub-sample of countries has shown that the interpersonal inequality changed by around 4 percent in response to the imputation of HNDI from the National Accounts. The accuracy of the presented estimate for the EU25 appears thus acceptable.

The observed development of income inequality in the EU25 during the second half of the 1990s can be comprehensively described by the term "convergence." The findings above reveal a convergence not only of national average income levels but also of inequality rates measured within and between the countries. The changes of inequality observed within countries correspond fairly well with what we would expect from the perspective of standard neo-classical trade theory and the theory of institutional competition (cf. Wildasin, 1991, 1992; Apolte, 2001; Deffains and Demougin, 2006). According to the former, the removal of trade barriers between the east and west of Europe has most likely lead to specialization on skill-intensive production in the EU15 and in more standardized production in the AC10. The demand for highly-qualified workers shifted from the east to west and demand for less qualified workers from the west to east. As a consequence, in EU15 countries the market incomes of highly qualified workers increased while those of the less qualified fell as a result of real wage losses or rising unemployment. At the same time, in the light of rising capital mobility, social policy was less effective in redistributing income from the rich to the poor, especially in the Scandinavian countries where the level of social support had been traditionally high (cf. Alber, 2002; Schmid, 2002; Hicks and Kenworthy, 2003; Ganßmann, 2004). The empirical findings in this section suggest that this goes hand in hand with a convergence of personal inequality within the countries.

In the AC10 the rapid growth of inequality, observed in previous studies for the first half of the decade, came to an end. The disruptions caused by the 
economic transition, which had brought about exploding unemployment and devaluation of wages, have been overcome. Workers with comparatively low qualification now benefited from rising demand for their labor, so their wages rose relative to the average and their unemployment risk lowered. The newly built up social protection schemes began to work properly after a period of "muddling through" (Wagener, 2002, p. 171) at the beginning of the decade (cf. Wagener, 1999; Fox, 2003; Adema and Ladaique, 2005).

Finally, the geographic decomposition above allows us to specify the amount by which interpersonal inequality has increased as a result of the eastward enlargement in 2004 - under the assumption, of course, that the income distribution did not significantly change between 2000 and 2004. Around the year 2000, the inter-personal inequality was a quarter higher in the EU25 than in the EU15. We would expect a jump in personal inequality of that size to bear a considerable risk of social tension in a socially integrated community of people living in a closely confined territory. In the EU25, where the population is spread over a large space and separated by national borders, and where the Member State is still an important unit of people's identification and socialization, the consequences are presumably less dramatic. Regardless of that, the finding that the income gap between the east and west accounts for more than 70 percent of the between-region inequality - and a fifth of the personal inequality - reveals the huge challenge which the enlargement has imposed on the regional cohesion policy of the EU.

\section{CONCLUSION}

In this study, the personal inequality of income in the EU25 is estimated at 0.216 points of the MLD. Which means the inequality in the EU is similarly high to that in the Member States with the most unequal distribution of income: Estonia, the United Kingdom and the Mediterranean countries of the EU15. It is smaller, indeed, than the inequality found by other studies in Canada, Russia, Indonesia or the Philippines. Furthermore, the study reveals that income levels in the EU25 converged during the second half of the 1990s on all investigated geographic levels: between the east and west of the EU, throughout the Member States and throughout persons within the Member States.

Not only did the income levels converge, but also the amount of inequality, both between Member States of the EU15 and the AC10 and between persons within the Member States. The convergence of within-country personal inequality is reflected primarily in a growth of inequality in the social-democratic welfare states of Scandinavia, accompanied by a reduction of inequality in the Mediterranean countries. This development may be attributable to intensified institutional competition caused by rising mobility of production factors in the EU. In the AC10, the rapid growth of inequality observed by other studies for the first half of the 1990s has come to an end. The inequality even lowered in two of the three AC10, which could be observed at two different points in time in the scope of this study, presumably as a result of economic stabilization, improvement of the capacities of social protection systems and a shift of demand for workers with lower qualification from the west to east. 
In the years 1999/2000, more than a quarter of the EU25's personal inequality was caused by inequality between regions. One fifth was attributed to the income gap between the old and new Member States. The inequality within countries, which falls under the responsibility of social policy of the Member States' governments, accounted for three quarters of the overall personal inequality of income in the EU25. All in all, this study reveals that, whilst on the one hand inequality is diminishing on all geographic levels, the enlargement in 2004 has led to a sudden jump of inequality by 25 percent. Dealing with the east-west income gap, which constitutes a new and significant source of personal inequality in the EU, falls into the domain of regional cohesion policy conducted at a European level.

\section{APPENDIX}

TABLE A1

Price Level Indices Applied in the Study

\begin{tabular}{|c|c|c|c|c|c|c|c|c|c|c|}
\hline \multirow[b]{4}{*}{ Country } & \multirow{4}{*}{$\begin{array}{c}\text { Conversion } \\
\text { Rate to } \\
\text { the Euro }\end{array}$} & \multicolumn{7}{|c|}{ HFCE } & \multirow{2}{*}{\multicolumn{2}{|c|}{ GDP for Euro }} \\
\hline & & \multicolumn{5}{|c|}{ For Local Currency Units } & \multirow{2}{*}{\multicolumn{2}{|c|}{ For Euro }} & & \\
\hline & & \multicolumn{4}{|c|}{ Temporal Index ${ }^{1}$} & \multirow{2}{*}{$\begin{array}{l}\mathrm{PPP}^{2} \\
2000\end{array}$} & & & \multirow{2}{*}{$\begin{array}{c}\text { Temporal } \\
\text { Index }^{1} \\
1995\end{array}$} & \multirow{2}{*}{$\begin{array}{l}\text { PPP }^{2} \\
2000\end{array}$} \\
\hline & & 1994 & 1995 & 1997 & 1999 & & $\begin{array}{c}\text { Temp. }{ }^{1} \\
1995\end{array}$ & $\begin{array}{l}\mathrm{PPP}^{2} \\
2000\end{array}$ & & \\
\hline$\overline{\text { Austria }}$ & 13.760 & 1 & 0.935 & 1 & I & 1.008 & 0.976 & 1.008 & 1.017 & 1.024 \\
\hline Belgium & 40.340 & l & 0.931 & I & l & 1.010 & 0.974 & 1.010 & 0.987 & 1.014 \\
\hline Cyprus & 1 & l & 1 & l & 0.963 & 0.855 & 0.861 & 0.872 & 0.846 & 0.850 \\
\hline Czech Rep. & l & l & l & l & 0.970 & 16.943 & 0.762 & 0.476 & 0.740 & 0.454 \\
\hline Denmark & l & l & 0.911 & I & 1 & 9.613 & 0.926 & 1.290 & 0.923 & 1.283 \\
\hline Estonia & l & I & l & l & 0.969 & 8.870 & 0.656 & 0.567 & 0.633 & 0.518 \\
\hline Finland & 5.946 & l & 0.899 & l & 1 & 1.197 & 0.936 & 1.197 & 0.953 & 1.132 \\
\hline France & 6.560 & l & 0.958 & l & I & 1.048 & 0.964 & 1.048 & 0.957 & 1.068 \\
\hline Germany & 1.956 & 0.949 & 1 & I & I & 1.055 & 1.003 & 1.055 & 1.033 & 1.100 \\
\hline Greece & 340.750 & I & $0.779^{\mathrm{a}}$ & l & I & 0.830 & $0.865^{\mathrm{a}}$ & 0.840 & 0.865 & 0.781 \\
\hline Hungary & I & $0.386^{\mathrm{b}}$ & 1 & I & 0.894 & 126.623 & 0.777 & 0.487 & 0.798 & 0.472 \\
\hline Ireland & 0.788 & I & 0.845 & I & 1 & 1.137 & 0.816 & 1.137 & 0.780 & 1.094 \\
\hline Italy & 1.936 & I & 0.876 & I & I & 0.965 & 0.797 & 0.965 & 0.794 & 0.930 \\
\hline Latvia & I & I & 1 & I & I & 0.326 & 0.582 & 0.582 & 0.581 & 0.507 \\
\hline Lithuania & l & l & l & I & I & 1.926 & 0.529 & 0.521 & 0.504 & 0.467 \\
\hline Luxembourg & 40.340 & 0.880 & I & I & I & 1.005 & 0.939 & 1.005 & 0.968 & 1.069 \\
\hline Malta & I & 1 & I & I & I & 0.683 & $0.920^{\mathrm{a}}$ & 0.725 & 0.920 & 0.672 \\
\hline Netherlands & 2.204 & 0.870 & I & I & 0.963 & 0.990 & 0.933 & 0.990 & 0.935 & 1.015 \\
\hline Poland & 1 & I & 0.568 & I & 0.910 & 2.297 & 0.718 & 0.573 & 0.745 & 0.523 \\
\hline Portugal & l & l & I & I & 1 & 0.822 & 0.895 & 0.822 & 0.870 & 0.796 \\
\hline Slovakia & I & I & I & I & I & 18.719 & 0.779 & 0.439 & 0.802 & 0.423 \\
\hline Slovenia & I & I & I & 0.818 & I & 147.701 & 0.908 & 0.721 & 0.920 & 0.702 \\
\hline Spain & 166.386 & I & 0.872 & I & I & 0.842 & 0.891 & 0.842 & 0.886 & 0.835 \\
\hline Sweden & l & l & 0.953 & l & l & 10.669 & 0.862 & 1.263 & 0.858 & 1.231 \\
\hline U.K. & I & I & 0.897 & I & 0.987 & 0.724 & 0.659 & 1.188 & 0.650 & 1.187 \\
\hline avalue & 4 & $\mathrm{G}$ & $1 \mathrm{de}$ & r. & & & & & & \\
\hline
\end{tabular}


Review of Income and Wealth, Series 55, Number 1, March 2009

TABLE A2

Real Household Net Disposable Income and GDP Per Capita (in 1,000 Euros)

\begin{tabular}{lrrrr}
\hline \hline & \multicolumn{2}{c}{ HNDI $^{1}$} & \multicolumn{2}{c}{ GDP $^{2}$} \\
\cline { 2 - 5 } & 1995 & 2000 & 1995 & 2000 \\
\hline Austria & 19.6 & 21.2 & 21.7 & 25.0 \\
Belgium & 18.9 & 21.0 & 21.2 & 24.0 \\
Cyprus & 12.5 & 14.4 & 15.0 & 16.9 \\
Czech Republic & 9.1 & 9.9 & 12.0 & 13.0 \\
Denmark & 18.1 & 20.1 & 22.3 & 25.1 \\
Estonia & 4.8 & 6.7 & 6.1 & 8.5 \\
Finland & 13.8 & 17.8 & 17.9 & 22.3 \\
France & 17.4 & 19.8 & 19.6 & 22.0 \\
Germany & 18.7 & 19.7 & 20.6 & 22.6 \\
Greece & 11.8 & 13.6 & 13.9 & 16.0 \\
Hungary & 6.8 & 8.2 & 8.7 & 10.7 \\
Ireland & 12.5 & 18.4 & 16.5 & 24.9 \\
Italy & 16.5 & 18.2 & 20.3 & 22.3 \\
Latvia & 3.5 & 5.0 & 5.0 & 7.0 \\
Lithuania & 4.4 & 6.0 & 6.0 & 7.5 \\
Luxembourg & 33.0 & 35.9 & 36.9 & 46.4 \\
Malta & 9.3 & 12.7 & 11.7 & 15.9 \\
Netherlands & 19.3 & 22.8 & 21.5 & 25.6 \\
Poland & 5.8 & 7.3 & 7.1 & 9.2 \\
Portugal & 10.3 & 12.3 & 12.4 & 14.9 \\
Slovakia & 6.4 & 7.3 & 8.1 & 9.5 \\
Slovenia & 10.2 & 12.3 & 12.2 & 15.0 \\
Spain & 13.5 & 15.9 & 15.4 & 18.5 \\
Sweden & 17.4 & 20.3 & 20.6 & 24.1 \\
United Kingdom & 16.7 & 19.8 & 19.3 & 22.3 \\
\hline \multicolumn{1}{c}{ Notes } & & & &
\end{tabular}

Notes:

${ }^{1}$ HNDI per capita at 2000 prices, PPP-adjusted, using the HFCE price indices as in Table A1.

${ }^{2}$ GDP per capita at 2000 prices, PPP-adjusted, using the GDP price indices as in Table A1.

TABLE A3

Spatial Decomposition of Inequality

\begin{tabular}{|c|c|c|c|c|c|c|c|c|}
\hline \multirow[b]{3}{*}{ Country } & \multirow[b]{3}{*}{ Region } & & & \multirow[b]{3}{*}{ EDI (Euro) ${ }^{1}$} & \multirow[b]{3}{*}{ (Abs.) } & \multicolumn{2}{|l|}{ MLD } & \multirow{3}{*}{$\begin{array}{l}\text { No. } \\
\text { of Obs. }\end{array}$} \\
\hline & & \multicolumn{2}{|c|}{ Population } & & & \multicolumn{2}{|c|}{ Contribution $^{2}$} & \\
\hline & & $(1000)$ & $(\%)$ & & & Abs. & $(\%)$ & \\
\hline \multirow[t]{6}{*}{ Austria } & Südösterreich & 1,743 & 21.8 & 18,168 & 0.0951 & 0.0207 & 17.6 & 1,743 \\
\hline & Westösterreich & 2,904 & 36.2 & 18,581 & 0.1119 & 0.0406 & 34.5 & 2,904 \\
\hline & Ostösterreich & 3,365 & 42.0 & 19,999 & 0.1319 & 0.0554 & 47.1 & 3,365 \\
\hline & Within regions & & & & 0.1167 & 0.1167 & 99.3 & \\
\hline & Between regions & & & & 0.0009 & 0.0009 & 0.7 & \\
\hline & Total & 8,012 & 100.0 & 19,087 & 0.1175 & 0.1175 & 100.0 & 8,012 \\
\hline \multirow[t]{6}{*}{ Belgium } & Région de Bruxelles & 962 & 9.4 & 19,306 & 0.1299 & 0.0122 & 6.6 & 235 \\
\hline & Région Wallonne & 3,343 & 32.6 & 17,918 & 0.1317 & 0.0430 & 23.3 & 824 \\
\hline & Vlaams Gewest & 5,946 & 58.0 & 20,560 & 0.2196 & 0.1274 & 69.0 & 1,300 \\
\hline & Within regions & & & & 0.1825 & 0.1825 & 98.9 & \\
\hline & Between regions & & & & 0.0020 & 0.0020 & 1.1 & \\
\hline & Total & 10,251 & 100.0 & 19,581 & 0.1845 & 0.1845 & 100.0 & 2,359 \\
\hline
\end{tabular}


TABLE A3 (continued)

\begin{tabular}{|c|c|c|c|c|c|c|c|c|}
\hline \multirow[b]{3}{*}{ Country } & \multirow[b]{3}{*}{ Region } & & & \multirow[b]{3}{*}{ EDI (Euro) $)^{1}$} & \multirow[b]{3}{*}{ (Abs.) } & \multicolumn{2}{|l|}{ MLD } & \multirow{3}{*}{$\begin{array}{l}\text { No. } \\
\text { of Obs. }\end{array}$} \\
\hline & & \multicolumn{2}{|c|}{ Population } & & & \multicolumn{2}{|c|}{ Contribution $^{2}$} & \\
\hline & & $(1000)$ & $(\%)$ & & & Abs. & $(\%)$ & \\
\hline \multirow[t]{9}{*}{ Poland } & Poludniowy & 8,093 & 20.9 & 5,920 & 0.1184 & 0.0248 & 15.9 & 6,533 \\
\hline & Wschodni & 6,908 & 17.9 & 5,362 & 0.1454 & 0.0260 & 16.7 & 5,210 \\
\hline & Poludniowo-Zachodni & 4,068 & 10.5 & 5,840 & 0.1534 & 0.0161 & 10.4 & 3,318 \\
\hline & Pólnocny & 5,753 & 14.9 & 5,652 & 0.1567 & 0.0233 & 15.0 & 4,733 \\
\hline & Pólnocno-Zachodni & 6,108 & 15.8 & 6,201 & 0.1759 & 0.0278 & 17.8 & 4,865 \\
\hline & Centralny & 7,723 & 20.0 & 6,655 & 0.1762 & 0.0352 & 22.6 & 6,716 \\
\hline & Within regions & & & & 0.1532 & 0.1532 & 98.3 & \\
\hline & Between regions & & & & 0.0026 & 0.0026 & 1.7 & \\
\hline & Total & 38,654 & 100.0 & 5,963 & 0.1558 & 0.1558 & 100.0 & 31,375 \\
\hline \multirow[t]{18}{*}{ Germany } & Thüringen & 2,440 & 3.0 & 14,801 & 0.0808 & 0.0024 & 1.9 & 477 \\
\hline & Sachsen & 4,443 & 5.4 & 15,611 & 0.0811 & 0.0044 & 3.4 & 825 \\
\hline & Sachsen-Anhalt & 2,633 & 3.2 & 15,638 & 0.0883 & 0.0028 & 2.2 & 475 \\
\hline & Brandenburg & 2,601 & 3.2 & 16,454 & 0.0893 & 0.0028 & 2.2 & 469 \\
\hline & Mecklenburg-Vorpommern & 1,783 & 2.2 & 15,072 & 0.1005 & 0.0022 & 1.7 & 281 \\
\hline & Baden-Württemberg & 10,493 & 12.8 & 18,990 & 0.1080 & 0.0138 & 10.8 & 1,259 \\
\hline & Rheinland-Pfalz + Saarland & 5,100 & 6.2 & 16,898 & 0.1173 & 0.0073 & 5.7 & 663 \\
\hline & Nordrhein-Westfalen & 18,000 & 21.9 & 18,582 & 0.1275 & 0.0279 & 21.8 & 2,331 \\
\hline & Niedersachsen & 7,911 & 9.6 & 18,735 & 0.1289 & 0.0124 & 9.7 & 891 \\
\hline & Schleswig-Holstein & 2,782 & 3.4 & 19,464 & 0.1413 & 0.0048 & 3.7 & 342 \\
\hline & Bremen & 662 & 0.8 & 17,551 & 0.1424 & 0.0011 & 0.9 & 94 \\
\hline & Bayern & 12,188 & 14.8 & 19,265 & 0.1452 & 0.0215 & 16.8 & 1,514 \\
\hline & Hessen & 6,058 & 7.4 & 20,070 & 0.1480 & 0.0109 & 8.5 & 742 \\
\hline & Berlin & 3,384 & 4.1 & 18,182 & 0.1537 & 0.0063 & 4.9 & 443 \\
\hline & Hamburg & 1,710 & 2.1 & 18,581 & 0.2010 & 0.0042 & 3.3 & 173 \\
\hline & Within regions & & & & 0.1249 & 0.1249 & 97.6 & \\
\hline & Between regions & & & & 0.0031 & 0.0031 & 2.4 & \\
\hline & Total & 82,188 & 100.0 & 18,250 & 0.1280 & 0.1280 & 100.0 & 10,979 \\
\hline \multirow[t]{11}{*}{ France } & Est & 5,189 & 8.8 & 16,000 & 0.0882 & 0.0078 & 6.0 & 1,080 \\
\hline & Ouest & 7,841 & 13.3 & 15,251 & 0.1076 & 0.0143 & 11.0 & 1,533 \\
\hline & Sud-Ouest & 6,243 & 10.6 & 15,554 & 0.1131 & 0.0120 & 9.2 & 1,118 \\
\hline & Centre-Est & 7,019 & 11.9 & 15,970 & 0.1140 & 0.0136 & 10.5 & 1,220 \\
\hline & Bassin Parisien & 10,484 & 17.8 & 15,574 & 0.1178 & 0.0210 & 16.1 & 1,839 \\
\hline & Nord & 4,004 & 6.8 & 14,468 & 0.1268 & 0.0086 & 6.6 & 675 \\
\hline & Méditerranée & 7,152 & 12.1 & 14,851 & 0.1393 & 0.0169 & 13.0 & 1,220 \\
\hline & Île de France & 11,038 & 18.7 & 21,087 & 0.1463 & 0.0274 & 21.1 & 1,602 \\
\hline & Within regions & & & & 0.1214 & 0.1214 & 93.6 & \\
\hline & Between regions & & & & 0.0083 & 0.0083 & 6.4 & \\
\hline & Total & 58,970 & 100.0 & 16,483 & 0.1298 & 0.1298 & 100.0 & 10,287 \\
\hline United & North East & 2,581 & 4.5 & 15,063 & 0.1605 & 0.0072 & 3.4 & 1,277 \\
\hline \multirow[t]{13}{*}{ Kingdom } & Wales & 2,937 & 5.1 & 16,037 & 0.1720 & 0.0087 & 4.2 & 1,345 \\
\hline & East Midlands & 4,191 & 7.3 & 17,330 & 0.1744 & 0.0126 & 6.0 & 1,784 \\
\hline & Scotland & 5,119 & 8.9 & 17,053 & 0.1838 & 0.0163 & 7.7 & 2,169 \\
\hline & Yorkshire \& Humber & 5,047 & 8.7 & 16,164 & 0.1845 & 0.0161 & 7.7 & 2,229 \\
\hline & South West & 4,936 & 8.5 & 17,274 & 0.1867 & 0.0159 & 7.6 & 2,214 \\
\hline & West Midlands & 5,336 & 9.2 & 17,307 & 0.1909 & 0.0176 & 8.4 & 2,222 \\
\hline & North West & 6,881 & 11.9 & 17,277 & 0.1954 & 0.0233 & 11.1 & 3,048 \\
\hline & Eastern & 5,419 & 9.4 & 19,946 & 0.2074 & 0.0194 & 9.3 & 2,398 \\
\hline & South East & 8,078 & 14.0 & 21,831 & 0.2313 & 0.0323 & 15.4 & 3,506 \\
\hline & London & 7,285 & 12.6 & 21,651 & 0.2659 & 0.0335 & 15.9 & 2,632 \\
\hline & Within regior & & & & 0.2030 & 0.2030 & 96.6 & \\
\hline & Between regions & & & & 0.0072 & 0.0072 & 3.4 & \\
\hline & Total & 57,809 & 100.0 & 18,442 & 0.2102 & 0.2102 & 100.0 & 24,824 \\
\hline
\end{tabular}


Review of Income and Wealth, Series 55, Number 1, March 2009

TABLE A3 (continued)

\begin{tabular}{|c|c|c|c|c|c|c|c|c|}
\hline \multirow[b]{3}{*}{ Country } & \multirow[b]{3}{*}{ Region } & & & \multirow[b]{3}{*}{ EDI (Euro) $)^{1}$} & \multirow[b]{3}{*}{ (Abs.) } & \multicolumn{2}{|l|}{ MLD } & \multirow{3}{*}{$\begin{array}{l}\text { No. } \\
\text { of Obs. }\end{array}$} \\
\hline & & \multicolumn{2}{|c|}{ Population } & & & \multicolumn{2}{|c|}{ Contribution $^{2}$} & \\
\hline & & $(1000)$ & $(\%)$ & & & Abs. & $(\%)$ & \\
\hline \multirow[t]{6}{*}{ Hungary } & Alföld és Észak & 4,144 & 41.2 & 4,907 & 0.1333 & 0.0549 & 36.8 & 918 \\
\hline & Dunántúl & 3,073 & 30.5 & 5,602 & 0.1368 & 0.0417 & 28.0 & 632 \\
\hline & Közép-Magyarország & 2,851 & 28.3 & 7,020 & 0.1462 & 0.0414 & 27.8 & 463 \\
\hline & Within regions & & & & 0.1380 & 0.1380 & 92.6 & \\
\hline & Between regions & & & & 0.0110 & 0.0110 & 7.4 & \\
\hline & Total & 10,068 & 100.0 & 5,718 & 0.1490 & 0.1490 & 100.0 & 2,013 \\
\hline \multirow[t]{7}{*}{ Greece } & Attiki (incl. greater Athens) & 3,885 & 35.6 & 14,120 & 0.1609 & 0.0572 & 28.6 & 916 \\
\hline & Nisia Aigaiou, Kriti & 1,095 & 10.0 & 10,634 & 0.1660 & 0.0166 & 8.3 & 512 \\
\hline & Voreia Ellada & 3,512 & 32.2 & 9,494 & 0.1954 & 0.0628 & 31.4 & 1,336 \\
\hline & Kentriki Ellada & 2,425 & 22.2 & 9,676 & 0.2094 & 0.0465 & 23.3 & 1,041 \\
\hline & Within regions & & & & 0.1833 & 0.1833 & 91.6 & \\
\hline & Between regions & & & & 0.0169 & 0.0169 & 8.4 & \\
\hline & Total & 10,918 & 100.0 & 11,295 & 0.2001 & 0.2001 & 100.0 & 3,805 \\
\hline \multirow[t]{10}{*}{ Spain } & Sur & 8,568 & 21.3 & 12,336 & 0.1589 & 0.0338 & 16.4 & 904 \\
\hline & Noreste & 4,089 & 10.2 & 17,471 & 0.1684 & 0.0171 & 8.3 & 677 \\
\hline & Comunidad de Madrid & 5,230 & 13.0 & 20,746 & 0.1714 & 0.0223 & 10.8 & 425 \\
\hline & Noroeste & 4,286 & 10.6 & 14,912 & 0.1784 & 0.0190 & 9.2 & 643 \\
\hline & Este & 11,129 & 27.6 & 18,351 & 0.2146 & 0.0593 & 28.7 & 989 \\
\hline & Centro (ES) & 5,255 & 13.1 & 13,100 & 0.2151 & 0.0281 & 13.6 & 839 \\
\hline & Canarias (ES) & 1,707 & 4.2 & 13,246 & 0.2196 & 0.0093 & 4.5 & 278 \\
\hline & Within regions & & & & 0.1889 & 0.1889 & 91.3 & \\
\hline & Between regions & & & & 0.0179 & 0.0179 & 8.7 & \\
\hline & Total & 40,263 & 100.0 & 16,025 & 0.2068 & 0.2068 & 100.0 & 4,755 \\
\hline \multirow[t]{8}{*}{ Italy } & Centro (IT) & 10,896 & 19.1 & 14,633 & 0.1380 & 0.0264 & 12.8 & 1,617 \\
\hline & Nord Est & 10,565 & 18.6 & 17,521 & 0.1574 & 0.0292 & 14.1 & 1,605 \\
\hline & Nord Ovest & 14,912 & 26.2 & 17,088 & 0.1650 & 0.0432 & 20.9 & 1,927 \\
\hline & Sud (IT) & 13,952 & 24.5 & 10,918 & 0.2165 & 0.0530 & 25.6 & 1,852 \\
\hline & Isole & 6,624 & 11.6 & 10,024 & 0.2735 & 0.0318 & 15.4 & 922 \\
\hline & Within regions & & & & 0.1837 & 0.1837 & 88.8 & \\
\hline & Between regions & & & & 0.0233 & 0.0233 & 11.2 & \\
\hline & Total & 56,949 & 100.0 & 14,365 & 0.2069 & 0.2069 & 100.0 & 7,923 \\
\hline
\end{tabular}

Notes:

${ }^{1}$ Mean EDI at 2000 prices PPP-adjusted (EU25 = 1) using Eurostat's price indices for HFCE.

${ }^{2}$ MLD weighted by the population share.

Source: LIS; Eurostat, New Cronos.

\section{REFERENCES}

Adema, W. and M. Ladaique, Net Social Expenditure, OECD, Social, Employment and Migration Working Papers, 52, Paris, 2005.

Alber, J., "Modernisierung als Peripetie des Sozialstaats?" Berliner Journal für Soziologie, 1, 5-35, 2002.

Apolte, T., "How Tame Will Leviathan Become in Institutional Competition?" Public Choice, 107, 359-81, 2001.

Atkinson, A. B., "Income Distribution in Europe and the United States," Oxford Review of Economic Policy, 12, 15-28, 1996.

, "Developing Comparable Indicators for Monitoring Social Inclusion in the European Union," in R. Hauser and I. Becker (eds), Reporting on Income Distribution and Poverty. Perspectives from a German and a European Point of View, Springer, Berlin, 174-91, 2003.

Atkinson, A. B. and A. Brandolini, "Promise and Pitfalls in the Use of 'Secondary' Data-Sets: Income Inequality in OECD Countries as a Case Study," Journal of Economic Literature, 39, 771-99, 2001.

(C) 2009 The Author

Journal compilation (C) International Association for Research in Income and Wealth 2009 
Atkinson, A. B., L. Rainwater, and T. M. Smeeding, "Income Distribution in OECD Countries. Evidence from the Luxembourg Income Study," Social Policy Studies, 18, OECD, Paris, 1995.

Atkinson, A. B., B. Cantillon, E. Marlier, and B. Nolan, Taking Forward the EU Social Inclusion Process. An Independent Report Commissioned by the Luxembourg Presidency of the Council of the European Union, Government of the Grand Duchy of Luxembourg, Luxembourg, 2005.

Beblo, M. and T. Knaus, "Measuring Income Inequality in Euroland," Review of Income and Wealth, 47, 301-20, 2001

Berger-Schmitt, R., "Unterschiede in den Lebensbedingungen innerhalb der Europäischen Union kaum verringert, Zentrum für Umfragen Methoden und Analysen (ZUMA)," Informationsdienst Soziale Indikatoren, 27, 1-5, 2002.

Boix, C., "The Institutional Accommodation of an Enlarged Europe," Friedrich Ebert Stiftung, Europäische Politik, 6, 1-10, 2004.

Bourguignon, F., "Decomposable Inequality Measures," Econometrica, 47, 901-20, 1979.

Brandolini, A., "Measurement of Income Distribution in Supranational Entities: The Case of the European Union," Banca d'Italia, Termi di Discussione, 623, 2007 (also published in S. P. Jenkins and J. Micklewright (eds), Inequality and Poverty Re-examined, Oxford University Press, Oxford, 2007).

Buhmann, B., L. Rainwater, G. Schmaus, and T. M. Smeeding, "Equivalence Scales, Well-Being, Inequality, and Poverty: Sensitivity Estimates Across Ten Countries Using the Luxembourg Income Study (LIS) Database," Review of Income and Wealth, 34, 115-42, 1988.

Castells, M., "The Construction of European Identity," in M. J. Rodriges (ed.), The New Knowledge Economy in Europe. A Strategy for International Competitiveness and Social Cohesion, Edward Elgar, Cheltenham, 232-41, 2002.

Coulter, F. A. E., F. A. Cowell, and S. Jenkins, "Equivalence Scale Relativities and the Extent of Inequality and Poverty," Economic Journal, 102, 1067-82, 1992.

Cowell, F., "On the Structure of Additive Inequality Measures," Review of Economic Studies, 47, $521-31,1980$.

Deffains, B. and D. Demougin, Institutional Competition, Political Process and Holdup, Humboldt University of Berlin, SFB 649, Discussion Paper, 2006/027, 2006.

Delhey, J., A Trade-Off Between Enlargement and Integration? An Analysis of Trust between EU Nationalities, Wissenschaftszentrum Berlin, Discussion Paper, SP I 2005/203, 2005.

Delhey, J. and U. Kohler, "From Nationally Bounded to Pan-European Inequalities? On the Importance of Foreign Countries as Reference Groups," European Sociological Review, 22, 125-40, 2006.

Dowrick, S. and M. Akmal, "Contradictory Trends in Global Income Inequality: A Tale of Two Biases," Review of Income and Wealth, 51, 201-29, 2005.

Durkheim, E., Über soziale Arbeitsteilung. Studie über die Organisation höherer Gesellschaften, Suhrkamp Taschenbuch Wissenschaft, Frankfurt a. M, 1992.

Edwards, G., "The Problems and Possible Future Developments of a European Identity in the European Union," in P. J. Anderson, G. Wiessala, and C. Williams (eds), New Europe in Transition, Continuum, London and New York, 66-80, 2000.

Eurobarometer, Standard Eurobarometer. Public Opinion in the European Union, 62, 2005.

European Commission, Unity, Solidarity, Diversity for Europe, Its People and Its Territory. Second Report on Economic and Social Cohesion, Brussels, Office for Official Publications of the European Communities, Luxembourg, 2001.

, A New Partnership for Cohesion. Third Report on Economic and Social Cohesion, Office for Official Publications of the European Communities, Luxembourg, 2004.

Eurostat, Nomenclature of Territorial Units for Statistics-NUTS. Statistical Regions of Europe, http:// ec.europa.eu/eurostat/ramon/nuts/home_regions_en.html, last update: 2007.

Eurostat, New Cronos Database, URL: http://epp.eurostat.ec.europa.eu, 2008.

Eurostat and OECD, Eurostat-OECD. Methodological Manual on Purchasing Power Parities, Office for Official Publications of the European Communities, Luxembourg, 2006.

Expert Group on Household Income Statistics, The Canberra Group. Final Report and Recommendations, Ottawa, 2001.

Fahey, T., "The Case for an EU-wide Measure of Poverty," European Sociological Review, 23, 35-47, 2007.

Förster, M. F., "The European Social Space Revisited: Comparing Poverty in the Enlarged European Union," Journal of Comparative Policy Analysis, 7, 29-48, 2005.

Foster, J. E. and A. A. Shneyerov, "Path Independent Inequality Measures," Journal of Economic Theory, 91, 199-222, 2000.

Fox, L., "Safety Nets in Transition Economies: A Primer, World Bank Institute," Social Protection Discussion Paper Series, SP 0306, 2003. 
Ganßmann, H., "Rheinische vs. atlantische Wohlfahrtsstaaten: stabile Gegensätze oder verschwindende Unterschiede?” Prokla. Zeitschrift für kritische Sozialwissen-schaft, 34, 375-400, 2004.

Gottschalk, P. and T. Smeeding, "Cross-National Comparisons of Earnings and Income Inequality," Journal of Economic Literature, 35, 633-87, 1997.

Headey, B. and R. Muffels, "Policy Goals and Outcomes in 'Three Worlds of Welfare Capitalism'," Schmollers Jahrbuch. Zeitschrift für Wirtschafts- und Sozialwissenschaften, 123, 27-41, 2003.

Heyns, B., "Emerging Inequalities in Central and Eastern Europe," Annual Review of Sociology, 31, 163-97, 2005.

Hicks, A. and L. Kenworthy, "Varieties of Welfare Capitalism," Socio-Economic Review, 1, 27-61, 2003.

Hill, R. J., "Measuring Substitution Bias in International Comparison Based on Additive Purchasing Power Parity Methods," European Economic Review, 44, 145-62, 2000.

Hoffmeister, O., "Statistische, wirtschaftliche und politische Effekte der Osterweiterung auf die soziale Ungleichheit in der EU," in A. Kutter and V. Trappmann (eds), Das Erbe des Beitritts-eine erste Bilanz für die mittel- und osteuropäischen Gesellschaften, Peter-Lang, 271-93, 2006.

Kaelble, H., "Eine europäische Gesellschaft?" in G. F. Schuppert, I. Pernice and U. Haltern (eds), Europawissenschaft, Nomos, Baden-Baden, 299-330, 2005.

Kangas, O. and V.-M. Ritakallio, Relative to What? Cross-National Picture of European Poverty Measured by Regional, National and European Standards, LIS Working Paper, 384, 2004.

Keating, M., The New Regionalism in Western Europe-Territorial Restructuring and Political Change, Cheltenham, 1998.

Lambert, P. J. and J. R. Aronson, "Inequality Decomposition and the Gini Coefficient Revisited," Economic Journal, 103, 1221-7, 1993.

LIS (Luxembourg Income Study), Micro database, harmonization of original surveys conducted by the Luxembourg Income Study, Asbl. Luxembourg, periodic updating, www.lisproject.org, 2008.

Milanovic, B., "Explaining the Increase in Inequality during Transition," Economics of Transition, 7, 299-341, 1999.

_ Surveys Alone," Economic Journal, 112(476), 51-92, 2002.

Morrisson, C. and F. Murtin, History and Prospects of Inequality among Europeans, http:// www.stanford.edu/ murtin/ArticleJan04.pdf, 2004.

Niedermayer, O., "Trust and Sense of Community," in O. Niedermayer and R. Sinnot (eds), Public Opinion and Internationalized Governance, Oxford University Press, New York, 227-45, 1995.

Pyatt, G., "On the Interpretation and Disaggregation of Gini Coefficients," Economic Journal, 86, $243-55,1976$.

Russel, H. and C. Whelan, Low Income and Deprivation in an Enlarged Europe, European Foundation for the Improvement of Living and Working Conditions, Office for Publications of the European Communities, Luxembourg, 2004.

Runciman, W. G., Relative Deprivation and Social Justice, Routledge and Kegan Paul/Penguin Books, London, 1966.

Schmid, J., Wohlfahrtsstaaten im Vergleich, Leske und Budrich, Opladen, 2002.

Sen, A., "Poor, Relatively Speaking," Oxford Economic Papers, 35, 153-69, 1983.

Shorrocks, A. F., "The Class of Additively Decomposable Inequality Measures," Econometrica, 48, $613-25,1980$.

Shorrocks, A. F. and G. Wan, "The Spatial Decomposition of Inequality," Journal of Economic Geography, 5, 59-81, 2005.

Smeeding, T. M., "Changing Income Inequality in OECD Countries: Updated Results from the Luxembourg Income Study (LIS)," in R. Hauser and I. Becker (eds), The Personal Distribution of Income in an International Perspective, Springer, Berlin, 205-24, 2000.

Smeeding, T. M. and H. Weinberg, "Toward a Uniform Definition of Household Income," Review of Income and Wealth, 47, 1-24, 2001.

Svennebye, L., "GDP per Capita, Consumption per Capita and Comparative Price Levels in Europe, Eurostat," Statistics in Focus, 3, 2008.

Theil, H., Economics and Information Theory, North Holland Publishing Company, Amsterdam, 1967.

Townsend, P., Poverty in the United Kingdom, Penguin Books, Harmondsworth, 1979.

Wagener, H.-J., "Social Security—A Second Phase Transformation Phenomenon?" in K. Müller, A. Ryll, and H.-J. Wagener (eds), Transformation of Social Security: Pensions in Central-Eastern Europe, Physica, Heidelberg, 13-30, 1999.

, "The Welfare State in Transition Economies and Accession to the EU," in P. Mair and J. Zielonka (eds), The Enlarged European Union. Diversity and Adaption, Frank Cass, London and Portland, 152-74, 2002.

(C) 2009 The Author

Journal compilation (C International Association for Research in Income and Wealth 2009 
Whelan, C., R. Layte, B. Maître, and B. Nolan, "Income, Deprivation and Economic Strain. An Analysis of the European Community Household Panel," European Sociological Review, 17, 357-72, 2001

Wildasin, D. E., "Income Redistribution in a Common Labor Market," American Economic Review, 81, 757-74, 1991 .

, "Relaxation of Barriers to Factor Mobility and Income Redistribution," in P. Pestieau (ed.), "Public Finance in a World of Transition," Public Finance, Supplement, 47, 216-30, 1992.

Yao, S. and J. Liu, "Decomposition of Gini Coefficients by Class: A New Approach," Applied Economics Letters, 3, 115-19, 1996.

Yitzhaki, S. and R. I. Lerman, "Income Stratification and Income Inequality," Review of Income and Wealth, 37, 313-31, 1991. 